\title{
PELAKSANAAN PENINGKATAN KESELAMATAN PASIEN DENGAN SASARAN PENGURANGAN RESIKO PASIEN JATUH DI RUMAH SAKIT
}

\author{
SRI HARVITA SARI MARPAUNG / 181101125
}

$\underline{\text { Sriharvitaaasm11@gmail.com }}$

\begin{abstract}
ABSTRAK
Latar belakang : Pencegahan resiko pasien jatuh dengan pelaksanaan peningkatan keselamatan pasien dengan sasaran pengurangan resiko pasien jatuh di rumah sakit.

Tujuan : untuk membantu dalam memberikan informasi tentang pelaksanaan peningkatan keselamatan pasien dengan sasaran pengurangan resiko pasien jatuh di rumah sakit. Metode : Menggunakan literature riview berdasarkan teks book, jurnal, e-book (10 tahun terakhir) dengan cara menganalisis, eksplorasi sumber dan kajian bebas.

Hasil : Pengaplikasian pelaksanaan peningkatan keselamatan pasien dengan sasaran pengurangan resiko pasien jatuh di rumah sakit.

Pembahasan : Mengidentifikasi pasien dengan resiko jatuh, dampak dari pasien jatuh dan pencegahan pasien jatuh.

Kesimpulan : Penerapan program keselamatan pasien dengan sasaran pengurangan pasien dengan resiko jatuh dapat meningkatkan mutu pelayanan yang lebih berkualitas dan dapat meningkatkan derajat kesehatan pasien.
\end{abstract}

Kata kunci : keselamatan pasien, rumah sakit, pasien dengan resiko jatuh.

\section{LATAR BELAKANG}

Program Keselamatan Pasien Rumah

Sakit atau yang lebih terkenal dengan

istilah Patient Safety adalah suatu

sistem dimana rumah sakit membuat

asuhan pasien menjadi lebih aman

Komponen - komponen yang

termasuk di dalamnya

adalah pengkajian risiko identifikasi

dan pengelolan hal yang berhubungan

dengan risiko pasien pelaporan dan

analisa insiden kemampuan belajar dari insiden dan tindak lanjutnya serta

implementasi solusi untuk

meminimalkan timbulnya risiko. Sistem ini mencegah terjadinya cedera

yang disebabkan oleh kesalahan

akibat melaksanakan suatu tindakan

atau tidak mengambil tindakan yang

seharusnya diambil.

Pasien yang dirawat di rumah sakit mempunyai hak untuk mendapatkan asuhan pasien yang aman melalui suatu 
sistem yang dapat mencegah terjadinya kejadian yang tidak diharapkan atau KTD.

Kesadaran akan hal tersebutlah yangmendasari pelaksanaan program patient safety dalam upaya mencegah terjadinya kejadian yang tidak diharapkan pada pasien yang dirawat perlu ditumbuh kembangkan kepemimpinan dan budaya rumah sakit yang mencakup keselamatan pasien dan peningkatan mutu pelayanan dalam sarana pelayanan kesehatan rumah sakit dalam hal ini terdapat berbagai pasien dengan berbagai keadaan dan berbagai macam kasus penyakit. Tiap - tiap pasien adalah suatu pribadi yang unik dengan berbagai kelainan dan kekhasan masing - masing.

\section{TUJUAN}

Tujuan dari penulisan ini adalah untuk membantu dalam memberikan informasi tentang pelaksanaan peningkatan keselamatan pasien dengan sasaran pengurangan resiko pasien jatuh di rumah sakit.

\section{METODE}

Metode yang digunakan dalam penulisan ini menggunakan literature riview berdasarkan teks book, jurnal, e- book (10 tahun terakhir) dengan cara menganalisis, eksplorasi sumber dan kajian bebas.

\section{HASIL}

Hasil yang diharapkan dari penulisan ini adalah dapat memberikan informasi mengenai pengurangan pasien dengan resiko jatuh dengan cara pengidentifikasian masalah yang dialami oleh pasien yang menyebabkan pasien memiliki resiko jatuh dan dapat memberi penanganan untuk pencegahan pasien jatuh

\section{PEMBAHASAN}

Jatuh adalah suatu kajadian dengan hasil seorang berbaring secara tidak sengaja di tanah atau lantai atau permukaan yang lebih rendah (WHO 2004 dalam Miake-Lye et al, 2013). Jatuh merupakan suatu yang dilaporkan penderita atau saksi mata, yang melihat kejadian dengan akibat seseorang mendadak terbaring atau duduk di lantai atau tempat yang lebih rendah dengan atau tanpa kehilangan kesadaran atau luka (Darmojo, 2004).

Jatuh memiliki definisi sebagai kejadian jatuh yang tidak disengaja dengan atau tidak terjadinya luka dengan hasil pasien terbaring dilantai atau terbaring 
diatas permukaan lain, atau orang lain atau objek lain (Weinberg, J et al, 2011). Apabila pasien jatuh dan berhasil berdiri atau kembali ketempat semula (tempat tidur, kursi, atau commode) itu hanya dapat disebut kejadian jatuh bila pasien terluka (Palomar Health, 2016).

Dalam pelaksaan penerapan keselamatan pasien dengan sasaran pasien dengan resiko jatuh adalah dengan mengenal pasien berdasarkan masalah yang dialami oleh pasien yang dapat menyebabkan pasien tersebut berada pada resiko jatuh.

Kejadian pasien jatuh selama perawatan di rumah sakit dapat meningkatkan bahaya dan cedera pada pasien. Oleh karena itu, upaya pencegahan pasien jatuh merupakan bagian penting dari pencapaian sasaran ke enam dari Sasaran Keselamatan Pasien, yaitu pengurangan resiko pasien jatuh. Pasien sendiri dan keluarga pasien merupakan bagian yang tidak terpisahkan dari pelayanan kesehatan yang paripurna, dan terlibat secara menyeluruh dalam upaya penyembuhan pasien. Dalam hal ini, pasien dan keluarga pasien perlu mengetahui hal-hal apa saja yang dapat meningkatkan resiko jatuh selama perawatan di rumah sakit, dan bersama- sama staf rumah sakit melakukan upaya pengurangan resiko jatuh tersebut.

Berikut yang dapat diidentifikasi pada pasien yang memiliki resiko cidera jatuh yaitu :

\section{A. Faktor Risiko Jatuh}

Dalam mengetahui pasien tersebut memiliki resiko jatuh adalah mengidentifikasi faktor faktor yang dapat menyebabkan pasien tersebut dapat jatuh diantaranya :

Faktor Intrinsik

a. Riwayat jatuh sebelumnya, dalam hal ini kita dapat melakukannya saat pengkajian maupun kita dapat mengetahui dari rekam medik pasien.

b. Gangguan sensori dan Gangguan neurologi, gangguan sensori dapat menurunkan kemampuan seseorang dalam menilai dan mengantisipasi bahaya yang terdapat dilingkunganya. Gangguan ini biasa terjadi pada golongan usia dewasa-tua dimana perlemahan dan memburuknya pengelihatan karena usia secara signifikan dapat meningkatkan risiko dari jatuh. 
c. Gangguan kognitif, dalam hal ini kita perlu mengkaji apakah pasien mengalami penurunan kognitif yang dapat mengganggu aktivitasnya. Dimensia, delirium, dan penyakit perkinson memiliki hubungan yang jelas dengan risiko terjadinya jatuh terutama saat perilaku agitasi dan berkeliaran muncul. Selain itu penurunan kognitif dan kognisi secara umum dapat mempercepat risiko jatuh pada pasien dewasa tua tanpa penyakit delirium atau tanpa penyakit dimensia (Feil dan Gardner, 2012).

d. Gangguan keseimbangan dan gaya berjalan, penurunan keseimbangan saat berjalan sering dialami oleh pasien lansia.

e. Gangguan urinaria, masalah ini menyebabkan pasien sering keluar masuk kamar mandi sehingga memungkinkan pasien terjatuh pada saat di kamar mandi.

f. Gangguan mobilitas, dalam hal ini kita dapat mengidentifikasi apakah pasien memiliki gangguan mobilitas sehingga dapat menyebabkan resiko jatuh.

Faktor Ekstrinsik

a. Faktor lingkungan pasien seperti lantai yang licin, ruangan yang memiliki banyak hambatan, tempat tidur yang tidak nyaman, kamar mandi yang tidak bersih dan licin, penerangan ruangan yang kurang.

b. Tenaga profesional kesehatan dan sistem pelayanan Selain kondisi lingkungan yang membahayakan pasien, sistem dari pelayanan kesehatan juga berpengaruh terhadap terjadinya pasien jatuh. Severo et al (2014), menyebutkan salah faktor ektrinsik jatuh adalah tatanan

Masalah yang dapat ditimbulkan dari kejadian pasien jatuh yaitu :

- Dampak Fisiologis

Dampak fisik yang disebabkan oleh jatuh berupa lecet, memar, luka sobek, fraktur, cidera kepala, bahkan dalam kasus yang fatal jatuh dapat mengakibatkan kematian. 
- Dampak Psikologis

Jatuh yang tidak menimbulkan dampak fisik dapat memicu dampak psikologis seperti; ketakutan, anxiety, distress, depresi, dan dapat mengurangi aktivitas fisik (Miake-Lye et al, 2013).

- Dampak finansial

Pasien yang mengalami jatuh pada unit rawat inap dapat menambah biaya perawatan, hal tersebut karena jatuh dapat menyebabkan luka pada pasien.

Langkah - langkah dalam melakukan pencegahan dan pengurangan dengan kasus pasien resiko jatuh yaitu :

\section{PROTOKOL PENCEGAHAN} PASIEN JATUH

Standar Resiko Rendah

$\checkmark$ Orientasi ruangan

$\checkmark$ Posisi tempat tidur rendah dan ada pengganjal (rem) pada roda tempat tidur

$\checkmark$ Ada pengaman di samping tempat tidur dengan/atau sisi pengaman

$\checkmark$ Mempunyai luas tempat tidur yang cukup untuk mencegah tangan, kaki dan bagian tubuh lainnya terjepit atau menggantung

$\checkmark$ Menggunakan alas kaki yang tidak licin untuk pasien anak yang bisa berjalan

$\checkmark$ Nilai kemampuan untuk ke kamar mandi dan dibantu bila membutuhkan bantuan

$\checkmark$ Memiliki akses untuk untuk menghubungi petugas kesehatan yang mudah dijangkau

$\checkmark$ Menjelaskan kepada pasien kegunaan alat - alat medis dan non medis yang berada di sekitarnya.

$\checkmark$ Lingkungan harus bebas dari peralatan yang mengandung resiko

$\checkmark$ Penerangan lampu yang cukup pada ruangan.

$\checkmark$ Dokumen tentang data pasien harus terjaga untuk memudahkan pemberi layanan kesehatan lainnya untuk mengetahui status kesehatan pasien tersebut.

\section{Standar Resiko Tinggi}

$\checkmark$ Memberikan tanda pengenal berupa gelang identitas pada pasien dengan warna kuning. 
$\checkmark$ Terdapat tanda peringatan pasien resiko jatuh

$\checkmark$ Pemberiaan informasi kepada pasien dan keluarga tentang protokol pencegahan pasien jatuh.

$\checkmark$ Membantu pasien saat akan melakukan mobilisasi

$\checkmark$ Penempatan tempat tidur disesuaikan dengan perkembangan pasien.

$\checkmark$ Alat yang tidak dibutuhkan dipindahkan atau dijauhkan dari lingkungan pasien.

\section{KESIMPULAN}

Peningkatan mutu pelayanan yang berkualitas yang bertujuan untuk meningkatkan kesehatan pasien dengan pemenuhan sasaran keselamatan salah satunya adalah pengurangan pasien dengan resiko jatuh melalui pengidentifikasian pasien yang benar serta mengenali dampak yang dapat ditimbukan oleh resiko jatuh pada pasien itu sendiri dan dapat melakukan penanganan pencegahan untk mengurangi angka pasien dengan resiko jatuh. Dengan demikian pelayanan kesehatan yang diberikan memberikan dampak positif bagi pasien maupun masyarakatn dan juga rumah sakit.

\section{REFERENSI}

Ainin. H. (2015). Faktor - Faktor yang Berhubungan dengan Pelaksanaan Pencegahan Resiko Jatuh yang Dilakukan Oleh Perawat di RS. Jurnal Keperawatan. STIKes Husada Surakarta.

Febriani. N. (2015). Pengetahuan Perawat tentang Penerapan Pelaksanaan Pencegahan Insiden pada Pasien Jatuh. Jurnal Keperawatan. Vol. 2. No. 1. Tahun 2015.

Nursalam. (2011). Manajemen Keperawatan: Aplikasi dalam Keperawatan Profesional, ed.3. Jakarta : Salemba Medika.

Oktaviana, Cindy. (2017). Hubungan Caring Perawat dengan Pencegahan Pasien Jatuh di Ruang Rawat Inap RS RK Charitas Palembang. Jurnal Keperawatan. Universitas Katolik Musi Charitas.

Oktaviani. S. (2012). Pengetahuan dan Sikap Keluarga tentang Pencegahan Kejadian Jatuh pada Lansia di 
Kelurahan Pahlawan Binjai. E journal. Vol. 1. No. 3. Tahun 2012

Oktaviani. H. Dkk. (2015). Hubungan

Pengetahuan dengan Kepatuhan Perawat dalam Pelaksanaan Standar Operasional Pencegahan Resiko Jatuh Pasien di RS Panti Waluya Surakarta. Jurnal Keperawatan. STIKes Kusuma Husada Surakarta

Panjawi. (2017). Kepatuhan perawat melaksanakan standar prosedur operasional pencegahan pasien jatuh berdasarkan faktor yang demografil motivasi. Jurnal Keperawatan. Vol.6. No.2. Tahun 2017.

Pramodio. (2017). Pencegahan Manajemen Kesehatan Pasien dalam
Usaha Pencegahan Kejadian Jatuh di RS Islam Klaten. Skripsi. Fakultas Ilmu Kesehatan Prodi Kesehatan Masyarakat Universitas Muhammadiyah Surakarta.

Simamora, R.H. (2018). Buku Ajar Keselamatan Pasien Melalui Timbang Terima Pasien Berbasis Komunikasi Efektif: SBAR

Rivai F, Sidin A.I, Kartika I. (2016). Faktor yang Berhubungan dengan Implementasin Keslamatan Pasien di RSUD Ajjappannge Soppeng Tahun 2015. Volume 05

Saputra. Dkk. (2019). Hubungan Peran Perawat dalam Pencegahan Pasien Jatuh. Jurnal Keperawatan. Vol. 2. No.2. tahun 2019. 